\title{
Financial sustainability of modern composting: the economically optimal scale for municipal waste composting plant in developing Asia
}

\author{
Andante Hadi Pandyaswargo • \\ Dickella Gamaralalage Jagath Premakumara
}

Received: 9 July 2013 / Accepted: 16 June 2014 / Published online: 23 July 2014

(c) The Author(s) 2014. This article is published with open access at Springerlink.com

\begin{abstract}
There is a widespread interest in converting organic waste into compost fertilizer to extend the life of landfills, create economic and environmental benefits, and ultimately reduce the pressure on local governments in managing the ever-increasing complexity of municipal solid waste. However, composting is still seldom considered as a strategic element. There is also very little evidence available of its economic feasibility. This study, therefore, aims to analyze key factors that influence the economic feasibility of municipal composting plant and identify a range of plant capacity or scale where a composting project could have higher opportunity to be financially sustainable. A cost-benefit analysis (CBA) was carried out using the data gathered from five composting plants in Asia, including Surabaya, Bali and Bekasi in Indonesia, Beijing in China, and Matale in Sri Lanka. The results identified that the medium-scale and lower largescale composting plants have an optimal opportunity for being financially feasible as compared with the smaller and larger capacity plants. The study also identified that the economic viability of the composting plants depends on the number of factors, such as selection of suitable processing methods, technologies, scale, quality of product and marketing strategies. The advantages of the medium and lower large-scale composting plants are (1) waste input and product quality are easier to control than larger scale
\end{abstract}

\footnotetext{
A. H. Pandyaswargo ( $\square)$

Graduate School of Environment and Energy Engineering,

Waseda University, Tokyo, Japan

e-mail: andante.hadi@toki.waseda.jp

D. G. J. Premakumara

Institute for Global Environmental Strategies, Kitakyushu Urban

Centre, Kitakyushu, Japan

e-mail: premakumara@iges.or.jp
}

compost plants, and (2) there are extra income opportunities such as tipping fees and carbon credits that are limited in the case of small-scale composting plants. The scale of composting plant is one of the key factors to be considered at the initial stage of planning composting plants.

Keywords Modern composting - Municipal solid waste management - Resource recovery - Economic feasibility . Asian developing countries

\section{Introduction}

Municipal solid waste management in Asian Cities

Developing countries in Asia have some similarities in their municipal solid waste management (MSWM), waste composition and its characteristics. Estimates show that many cities in developing countries allocate $20-50 \%$ of their annual budget for MSWM, even though 30-60\% of all urban municipal waste (MSW) remains uncollected and $<50 \%$ of the population is served (UNEP 2009). The composition of MSW in developing Asia is dominated by organic waste and collection is often done without proper waste separation at source. The most common existing treatment method is landfill, as it remains the cheapest and easiest way of disposing of the MSW. However, most landfills in developing countries are poorly designed and maintained, effectively turning into open, unsanitary dumpsites (ADB 2011).

The improper MSW collection and treatment contribute severe public and environmental health issues, including the global warming since organic waste is the main source of methane gas emissions through open dumping and landfill disposal (Sang-Arun et al. 2009). Thus, converting 


\section{Municipal Waste Composition}

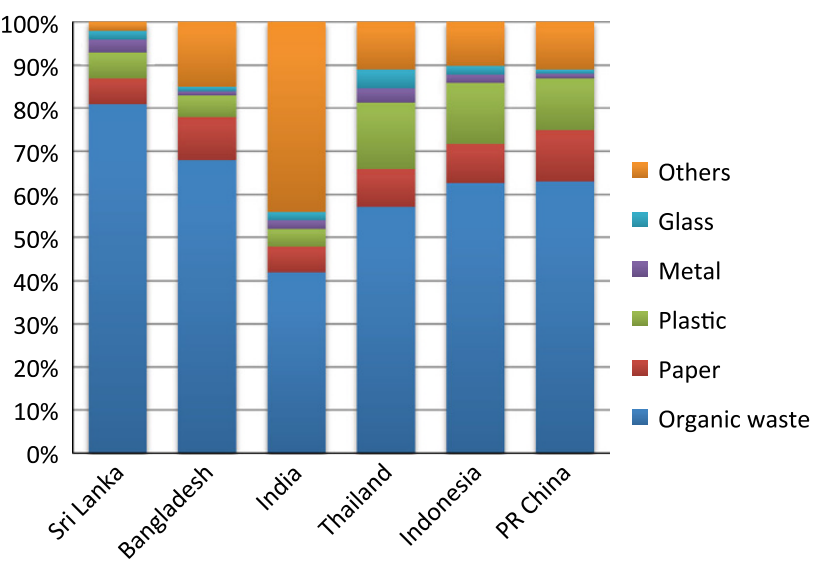

Fig. 1 Municipal waste compositions in Sri Lanka, Bangladesh, India, Thailand, Indonesia and PR China

this high level of organic waste into resource recovery systems presents a sizeable untapped potential for extending the life of landfills, creating economic and environmental benefits, and ultimately reducing the pressure on municipalities in developing countries to manage the everincreasing complexity of MSWM (Premakumara et al. 2011).

The potential of composting in municipal solid waste management

Figure 1 shows the percentage of MSW composition in six Asian countries. It shows that over $50 \%$ of MSW generated in these countries is organic waste. Further, MSW in developing countries is characterized by a significantly higher density and moisture, mainly organic waste with low caloric values (an average 700-1,000 kilocalories) (ADB 2011). Technically, high-moisture waste caused by the high percentage of organic waste makes it more suitable for biological treatment rather than thermal treatment (Rand et. al. 2000). Moreover, due to this particular waste characteristic, integrated waste management involving composting is more energy efficient and has lower environmental impact (Pandyaswargo et. al. 2012).

Developing countries in Asia generally practice two biological treatment methods for organic waste management, such as aerobic composting and anaerobic digestion (AD). The AD method allows both material and energy recovery. The output of material recovery is compost fertilizer and the outputs of energy recovery are electricity and heat. Though AD plants are getting more popular due to these two benefits, they are highly sensitive towards input quality. Thus, AD technology has been commonly used in Asia to treat animal manure, kitchen and agricultural waste because of the uniformity and purity of organic content.
However, some attempts to apply this technology to treat MSW have not been so successful in many Asian cities where segregation of waste at source is poor (Mazumdar 2012). Moreover, the rate of implementation is hindered by the high up-front investment, maintenance costs and technical skill requirements. These failures can be seen in Delhi, Bangalore, Lucknow and other cities in India (Ambulkar and Shekdar 2004). Similarly, municipal waste AD plants in China also faced problems and operational difficulties (Zheng 2012).

Aerobic composting, on the other hand, is more forgiving towards input quality (Hoornweg and Bhada-Tata 2012) and requires less investment and operational costs (Aye and Widjaya 2006). Composting can be applied in various scales, from small, more community-based approaches to medium and large scales, centralized facilities that can handle several hundred tonnes of MSW per day (see Table 1). A number of composting techniques are available in developing countries in Asia, such as household bins, windrows or piles that are aerated with poles and turned with front-loaders or simple spades, and in-vessel or enclosed systems (drums and agitated bed technologies or any technical system enclosed in a building require complex equipment) (Eawag Sandec 2008).

Key factors for the sustainability of composting schemes

Although developing countries in Asia have gained more experience in implementing composting than $\mathrm{AD}$ projects, MSW composting is not a problem-free solution either (Hargreaves et al. 2008). Most commonly, composting systems have failed due to economic and technical reasons.

\section{Economic failure}

One of the popular economic failures is a lack of market for the compost that is produced by the compost plants. Market acceptance of compost fertilizer relies on a wide range of criteria, including the price, quality and consistency of the product. It should also be free from contaminants such as heavy metals, glass, inert materials, and also plant and animal pathogens. It was evident that a larger scale composting plants often receive a large volume of mixed waste, which may contain contaminants (Williams 2005).

In addition to the income from compost sells, the compost plants can earn additional income from the tipping fees and the Certified Emission Reduction (CER) if the plant is registered and approved as Clean Development Mechanism (CDM) project. In practice, more than $98 \%$ of 
Table 1 Comparison of composting at different scales

\begin{tabular}{|c|c|c|}
\hline Small & Medium & Large \\
\hline $\begin{array}{l}\text { Small-scale (maximum } 5 \text { tonnes/day) } \\
\text { composting schemes which are commonly } \\
\text { integrated into the community MSW } \\
\text { collection system }\end{array}$ & $\begin{array}{l}\text { Medium-scale composting plants handle } \\
\text { around 5-100 tonnes/day of organic waste } \\
\text { collected from city markets and/or } \\
\text { residential areas }\end{array}$ & $\begin{array}{l}\text { Large-scale composting plants accept over } 100 \\
\text { tonnes/day of organic waste collected from } \\
\text { city markets and mixed residential areas and } \\
\text { mostly located outside of the city }\end{array}$ \\
\hline $\begin{array}{l}\text { Apply a simple, low-cost technology with high } \\
\text { labour-intensive methods. Common } \\
\text { composting methods are manual windrow, } \\
\text { box composting and vermicomposting are } \\
\text { commonly used }\end{array}$ & $\begin{array}{l}\text { Semi-mechanized plants with mechanical } \\
\text { windrow and aerated static piles are } \\
\text { commonly applied }\end{array}$ & $\begin{array}{l}\text { Highly mechanized and low labour-intensive } \\
\text { methods, such as mechanical windrow and } \\
\text { in-vessel methods }\end{array}$ \\
\hline $\begin{array}{l}\text { Low capital and operational costs, easy to start } \\
\text { and operate with minimum know-how, } \\
\text { reduce transportation costs and good-quality } \\
\text { compost }\end{array}$ & $\begin{array}{l}\text { Medium capital and operational costs, more } \\
\text { control of operation }\end{array}$ & $\begin{array}{l}\text { High capital and operational costs, more } \\
\text { control of operation }\end{array}$ \\
\hline $\begin{array}{l}\text { Reliance on cooperation of citizens, less } \\
\text { control of implementation }\end{array}$ & $\begin{array}{l}\text { Need trained staff, more expensive, } \\
\text { additional knowledge on project } \\
\text { management and marketing }\end{array}$ & $\begin{array}{l}\text { Need highly trained staff, highly expensive, } \\
\text { additional knowledge on project management } \\
\text { and marketing and poor-quality compost } \\
\text { products }\end{array}$ \\
\hline
\end{tabular}

Source: compiled by the authors

the registered CDM composting projects fall in the category of medium- to large-scale composting plant (Fenhann 2012). The smaller composting plants are not qualified to receive carbon credits due to insufficient greenhouse abatement potential set by the United Nations Framework Convention on Climate Change (UNFCCC) regulation (Yenneti and Premakumara 2011). Thus, the small-scale composting plants are often dependent on municipal provision to launch and sustain its operation. (Zurbruegg et al. 2004).

\section{Technical failure}

Composting plants have experienced two kinds of technical failures: first, the failure of the mechanical systems those manipulate waste streams before biological process starts; second, the failure of the decomposition process itself mainly attributable to failure to create an environment for the biological process to thrive. The technological failure of composting is primarily a failure of the mechanical pre-processing systems. The large-scale composting facilities with the complex mechanical preprocessing to remove non-compostable materials have largely failed at their tasks. There is hardly any mechanical system which could ever adequately identify and separate all of the materials in the mixed waste to ensure the production of good-quality compost. In addition, there is a failure in the composting process itself due to the failure in understanding the nature of biological processes. Compost bacteria, insects, and microorganisms require certain environmental conditions to thrive. If these conditions are absent or interrupted, it badly affects the composting process and its quality.

\section{Objectives}

The objective of this study is to analyze factors that could affect the economic feasibility of municipal waste composting plant and to find a range of plant capacity or scale where a composting project could have higher opportunity to be financially sustainable based on a comparative analysis in the study.

Estimation results of this study represent only the discussed case study plants. However, the sensitivity analysis part, which highlighted the significant factors that affect the economic feasibility of a composting plant with different capacities, could be used as an approximate economic guideline for investment in a composting plant, in the developing countries of the Asian region.

The paper is divided into four sections. After this brief introduction, "Materials and methods" elaborates on the data and research methodology. Then, "Results and discussions" presents the results of CBA and "Sensitivity analysis" provides sensitivity analysis to show how the plants would perform under different conditions. Finally, the conclusion, recommendations and suggestions for further studies are offered in "Conclusions and recommendations" and "Further studies".

\section{Materials and methods}

Scope and boundaries

The study selected five case studies from three different countries to represent three ranges of composting plant capacities (small, medium, large). The selected small-scale 


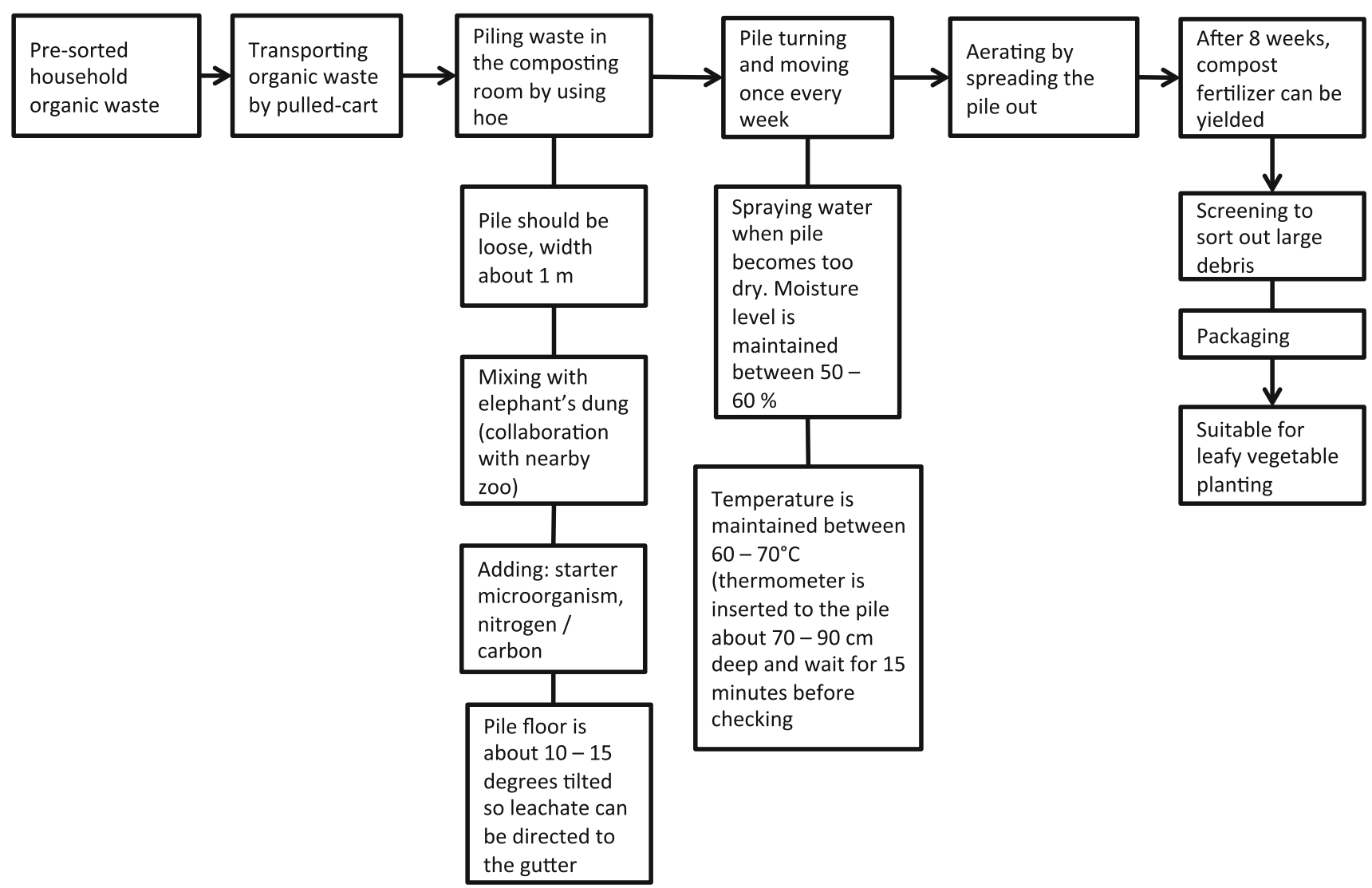

Fig. 2 Composting scheme practiced in Surabaya. Source Christianto 2005

municipal waste composting plants are located in Surabaya city in Indonesia (0.6 TPD) — note that the analyzed composting activity in this plant is only the open windrow one and not the takakura basket method (Pusdakota 2014) (Christianto 2005)—and Matale City in Sri Lanka (1 TPD). The medium-scale municipal waste composting plant is situated in Bali, Indonesia (51 TPD). Also, large-scale municipal waste composting plants selected in this study are in Beijing, China (638 TPD) and Bekasi, Indonesia (200 TPD). The CBA included all direct economic costs such as land acquisition cost, machineries, fuel, manpower, etc. based on the specific plants discussed in accordance with the current local market prices.

\section{Applied composting techniques and outputs}

Composting plants in this study use the different composting methods. Figures 2, 3, 4, 5 and 6 show the composting process in each plant. The input for the small-scale plants in Surabaya and Matale is sourceseparated household kitchen waste. The Surabaya compost pile is the open windrow and the Matale plant is applied ventilated brick boxes (box composting method). Compost piles are manually turned and the compost product is used for agriculture. Brinton suggests that compost made by pure organic waste is suitable for vegetable planting (Brinton 2000). The heavy metal test using Atomic Absorption Spectrometer (AAS) conducted by the Sri Lankan Industrial Technology Institute showed that there is no Cadmium $(\mathrm{Cd})$ detected, Chromium $(\mathrm{Cr})$ $30 \mathrm{mg} / \mathrm{kg}$, Copper $(\mathrm{Cu}) 42 \mathrm{mg} / \mathrm{kg}$, Mercury $(\mathrm{Hg})$ not detected, Nickel (Ni) $11 \mathrm{mg} / \mathrm{kg}$, and Zinc (Zn) $113 \mathrm{mg} / \mathrm{kg}$ in the Matale compost product (Jayaratne 2013). This result is meeting the Sri Lankan standard for heavy metal limit in fertilizers (UN ESCAP 2010; Jayaratne 2009).

The input for the medium-scale plant in Bali is postcollection, manually separated organic waste from the mixed municipal waste. The technology used is forced aeration composting using a blower. The product of this plant is suitable for soil revitalization and farming. The research conducted by Zurbruegg et al. (2012) has shown that the product has a concentration metal as far below the Indonesian standards and it is meeting all the specifications for compost from organic waste.

The input for the large-scale plant in Bekasi is from the traditional market, the technique applied is open windrow, excavator is used for turning the pile, and the output is used 

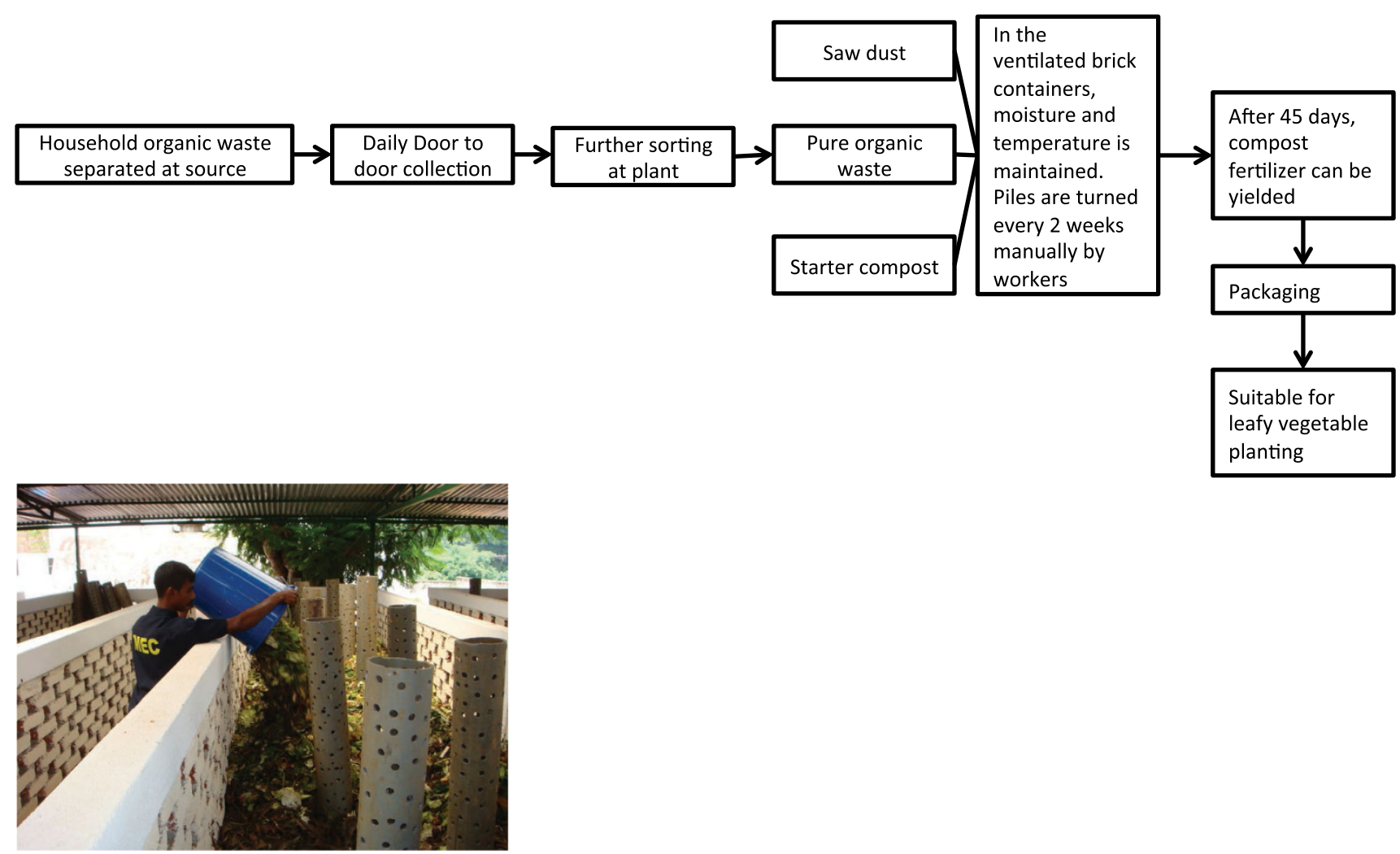

Fig. 3 Composting scheme in Matale Plant, Sri Lanka. Source Jayaratne 2013

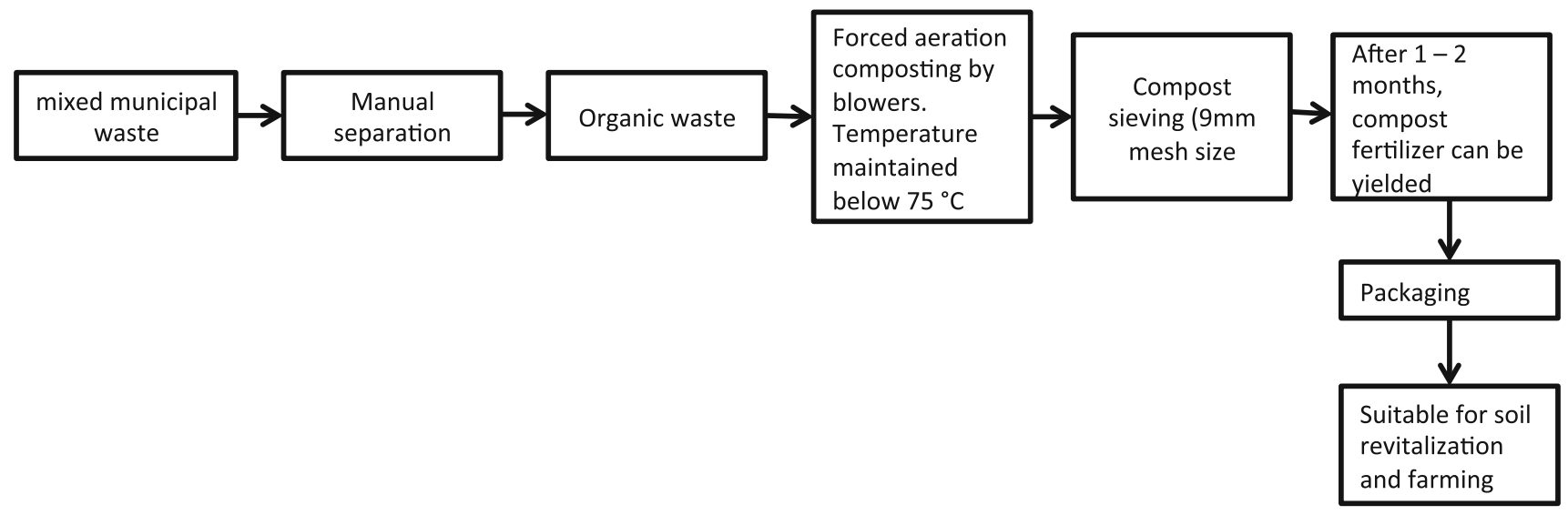

Fig. 4 Composting scheme in Temesi, Bali. Source Zurbruegg et al. (2012)

as palm plantation fertilizer and soil rehabilitation. The input for the large-scale plant in Beijing is from the municipal waste that is sorted manually after collection. The technology used is fermentation in tunnel-composting systems with forced aeration. The product is used for soil rehabilitation, landfill cover soil, and farming. The compost products of mixed municipal waste usually have higher heavy metal contents (Brinton 2000); therefore, the composting main role is waste volume reduction (Zheng 2012) and the product main use is for soil rehabilitation.
Financial data collection method

The relevant data related to initial investment costs (e.g. land acquisition, buildings, machineries), operational and maintenance costs (e.g. utilities, manpower, fuel cost), and benefits (e.g. fertilizer price, tipping fee, CER) were collected from local plant managers and national waste management experts through extensive on-site interview, telephone communication and literature review. The collection of data regarding the components of influencing 


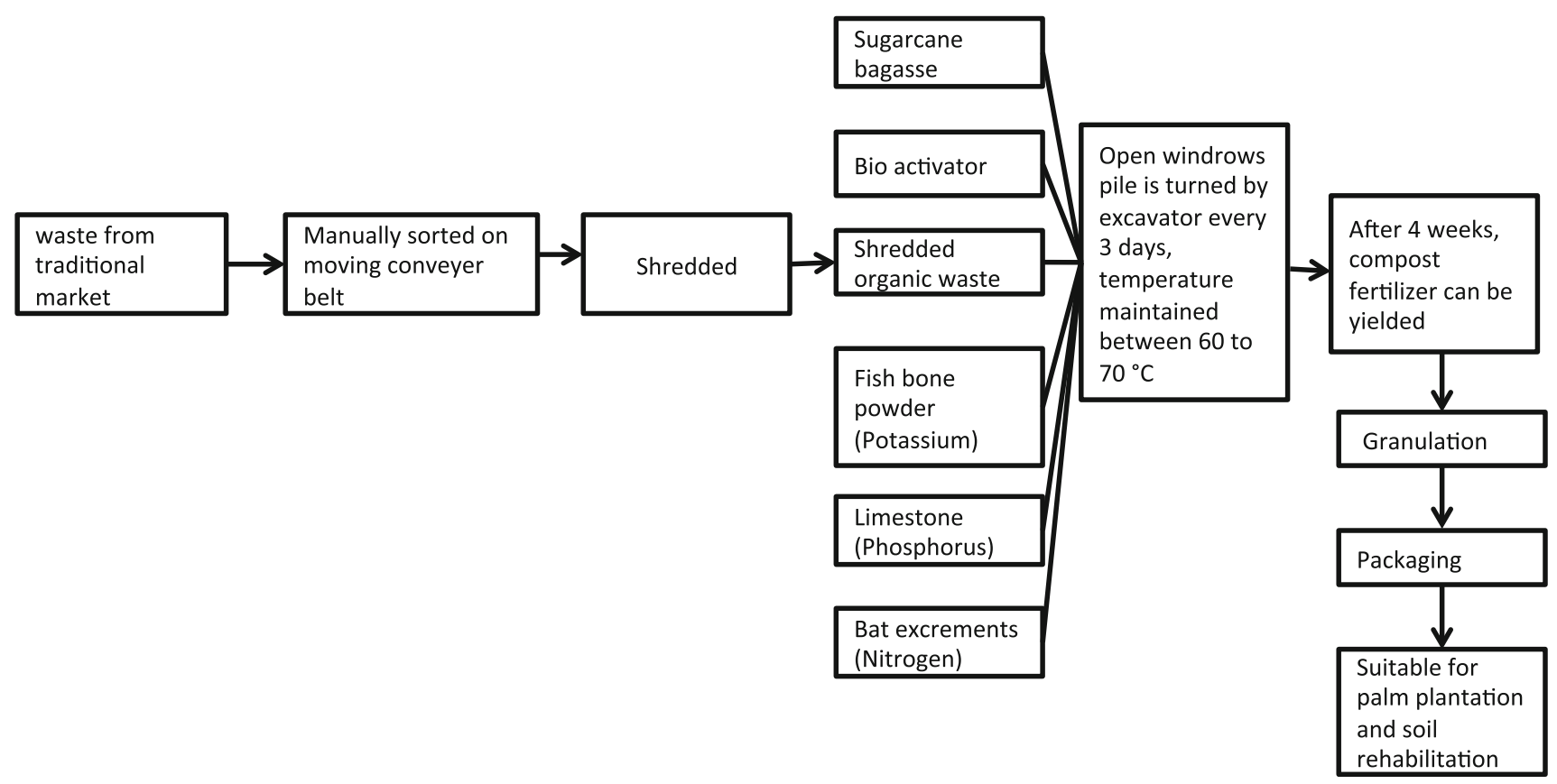

Fig. 5 Composting scheme in Bantar Gebang, Bekasi. Source Lumbantoruan (vice managing director of Bantar Gebang waste management plant), personal communication, April 5, 2011

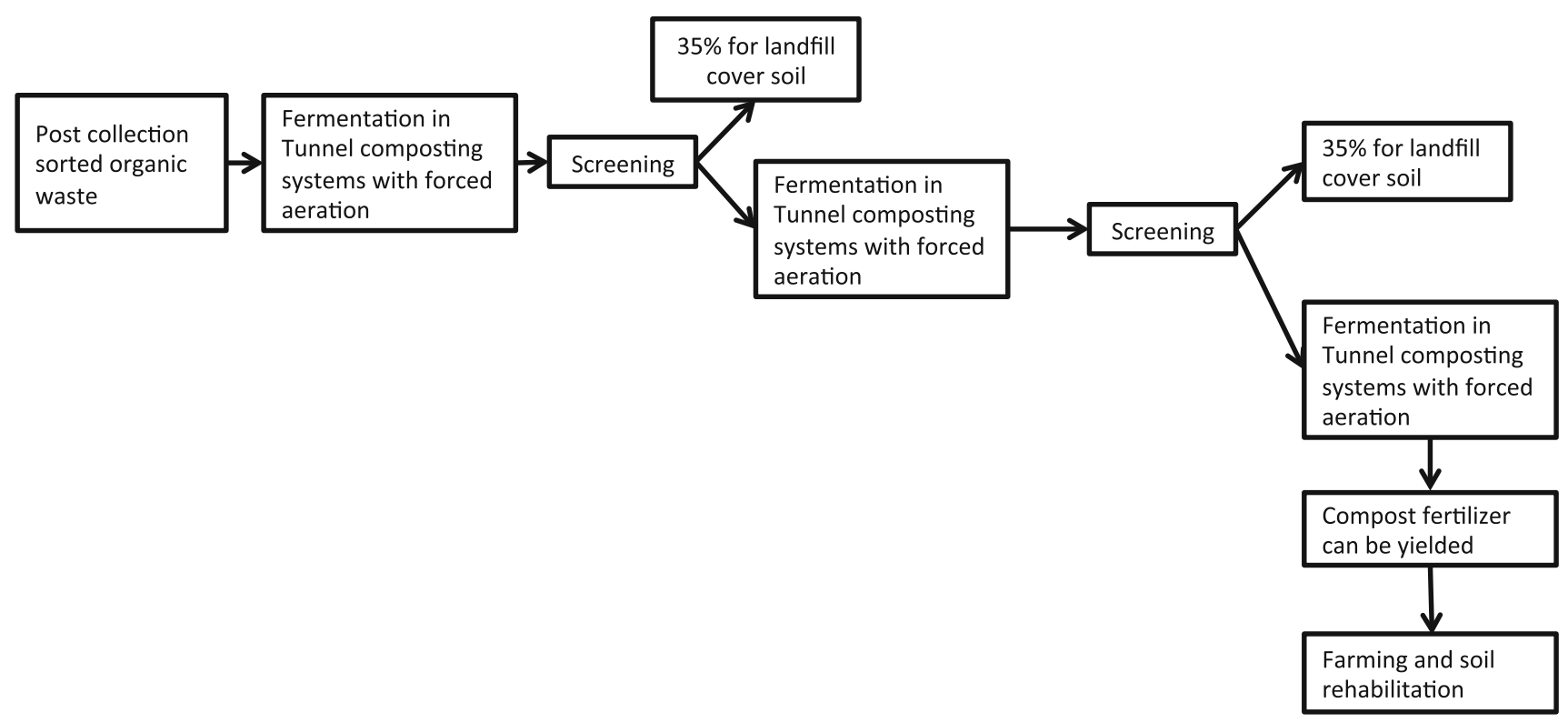

Fig. 6 Composting scheme in Nangong, Beijing, China. Source Zheng (2012), personal communication 3 July, 2012

cost and benefit of composting plants was guided by the inventory data lists recommended by Nordic guideline for cost-benefit analysis (Skovgaard et al. 2007) and Costs for Municipal Waste Management in the European Union (EU) (Hogg 2002).

The most updated financial data such as the national average of interest rate and inflation rates are taken from Trading economics database (Trading Economics Interest rate by country 2012). To determine allocation of investment overtime, the lifetime of all projects was estimated to be 15 years referring to the CBA and life-cycle case studies of composting facilities in Italy (Skovgaard et al. 2007) and in the United States (Haaren 2009) (Fig. 7).

Methods for economic analysis

For its simplicity and long-term accuracy (Ong 1997), the Big Mac Index is used to test the level of purchasing power 


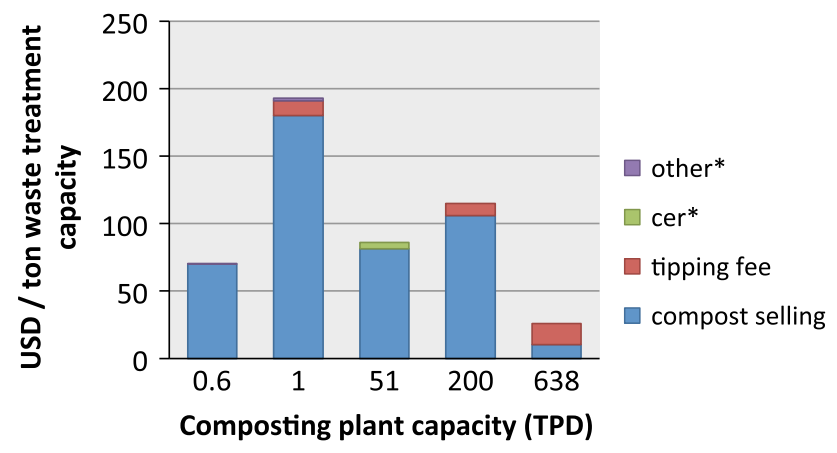

Fig. 7 Benefit components from different capacity composting plant. Other (asterisk) selling recyclable material and composting kit received by the small-scale plants. CER (asterisk) accumulated revenue from the 10 -year CDM contract divided by the weight of organic waste treated throughout 15 years of assumed plant life time

of the three different currencies involved in this study: Renminbi (RMB), Indonesian Rupiah (IDR), and Sri Lankan Rupees (LKR). In January 2013, the Big Mac price level relative to the United States is -35 for Indonesia, -37 for Sri Lanka, and -41 for China (The Economist 2014). It shows that the three currencies are within the similar level of purchasing power.

To perform an economic analysis, cost-benefit analysis (CBA) methodologies are often used (Finnveden et al. 2007). A large number of studies have been conducted on waste-related economic assessments, which often compare different technology options (Aye and Widjaya 2006; Menikpura et al. 2012; Ngoc and Schnitzer 2009; Reich 2005). However, multinational comparative study focusing on a single waste management method practiced in different capacities, particularly for the composting method, is rare. To address this knowledge gap, this study focuses on composting in various capacities from operative composting plants in Asia. The selected composting plants are located in five cities of three countries: Surabaya, Bali and Bekasi in Indonesia, Beijing in China, and Matale in Sri Lanka.

The three formulas used in this study of CBA are Net Present Value (NPV), Benefit-Cost Ratio (BCR), and amortization time estimation formula, widely implemented for waste-related projects (Mishan 1972; Demir and Arisoy 2007; Bhatia 1977; Ali et al. 2012; Soeylemez 2000) to determine the economic feasibility of the project.

$\mathrm{NPV}=\sum_{t=0}^{n} \frac{B_{t}-C_{t}}{(1+i)^{t}}$

where $B$ as the benefit, $C$ as the cost, $i$ as the discount rate, and $t$ as the time of the cash flow.

$\mathrm{BCR}=\frac{\sum_{t=0}^{n} B_{t} /(1+r)^{t}}{\sum_{t=0}^{n} C_{t} /(1+r)^{t}}$
BCR is calculated as the present value of the benefit divided by the present value of cost. Finally, the amortization time is calculated as the year when the cumulative cash flow becomes positive during the lifetime of the project.

NPV is defined as a measure of discounted cash inflow to present cash outflow to determine whether a prospective investment will be profitable. A positive NPV means that the project would be profitable and a negative NPV means that the project would not be profitable. BCR indicates the amount of benefits returned for each dollar invested. The bigger it is, the more benefit a project generates for each dollar invested.

\section{Results and discussions}

It was identified that the investment cost of the selected composting plants is subsidized by the external organizations, such as national governments, Local Governments (LGs), universities, and other multilateral and donor agencies. For example, the national and local government provided the land for Beijing composting plant. Bekasi composting plant acquired its land on a lease basis, with a price of $20 \%$ of the tipping fee, paid by the Jakarta provincial government (the waste source) to the Bekasi city government (the plant location). Similar to that, the Matale composting plant also located in the local government's land under the lease contract.

The operation and maintenance cost is highly dependent on the composting process adopted in the plant. When the traditional open windrow is practiced, operation requires more manpower. When sophisticated technologies such as forced aeration aerobic process are practiced, more electricity is required. It is true in the Bali (51 TPD) and Beijing (638 TPD) composting plants. The 200 TPD plant in Bekasi used the open windrow method and further pelletized the product so that it require both electricity and manpower. The operation and maintenance costs also rely on the electricity price. The electricity price is highly subsidized in Indonesia (International Institute for Sustainable Development 2012). Thus, the use of higher technology is less costly than Sri Lanka and China (Table 2).

The sources of income are slightly different in the various scales of composting plants discussed in the study. However, it was evident that all composting plants are receiving income from selling their compost products at the market. Smaller plants have better price for their compost products because of the good quality and the application of retail price. While the organic waste received by these small plants is relatively pure organic and sorting is done at 
Table 2 CBA inventory data for composting

\begin{tabular}{|c|c|c|c|c|}
\hline Financial data & Infrastructure & Equipment & Operation and maintenance & Variable cost \\
\hline Interest rate & Land acquisition & Shredder & Capacity of plant & $\begin{array}{l}\text { Manpower (Director, Accounting } \\
\text { staff, Workers) }\end{array}$ \\
\hline Inflation rate & Paving, concrete & Screw mixer & $\begin{array}{l}\text { Requirements for land per unit of } \\
\text { capacity }\end{array}$ & $\begin{array}{l}\text { Fuel (for machineries and } \\
\text { transportation) }\end{array}$ \\
\hline \multirow{7}{*}{$\begin{array}{l}\text { Allocation of investment } \\
\text { overtime }\end{array}$} & Process building & Turning Machine & Plant utilization rate & Disposal of rejects \\
\hline & Pools & Sieve & The choice of technology/process & \multirow[t]{6}{*}{ Water and electricity consumption } \\
\hline & Biofilter & $\begin{array}{l}\text { Eddy current } \\
\text { separator }\end{array}$ & Cost for daily operation & \\
\hline & Weighing bridge & Loader & $\begin{array}{l}\text { Revenues for sale product } \\
\text { (compost) }\end{array}$ & \\
\hline & Office Building & Hopper & & \\
\hline & Utilities & \multirow[t]{2}{*}{ Blowers, Fans } & & \\
\hline & Wall & & & \\
\hline
\end{tabular}

Source: (Skovgaard et al. 2007) and (Hogg 2002)

the source. However, when the plant capacity is bigger and the input is mixed municipal waste, the control of quality became difficult and result for low market price. To overcome this problem, the Bekasi (200 TPD) plant made some attempts to increase the value of composting products by pelletizing its final outputs. According to the plant manager, by applying this strategy, the demand for its compost product has been increased, widely from largescale plantations across the country.

It was further identified that tipping fee from the government is mainly only received by the large-scale composting plants (the small-scale Matale plant receive it as a "collection fee" because it is more of a community scale). Furthermore, only the medium composting plant was able to receive CER benefit. The tipping fee plays a significant role in the financial sustainability of the Beijing Nangong (638 TPD) plant and the Bekasi plant (200 TPD) as it covers the necessary operational cost.

Cost-benefit analysis

\section{Small-scale composting plants}

The amount of organic waste received in Rungkut Lor community-based composting plant, in Surabaya, is 0.6 TPD and it produces 0.1 tonne of compost fertilizer daily. The capital costs include various organizations subsidized land acquisition, construction, equipment and other planning and managerial initial cost of project establishment. The $190 \mathrm{~m}^{2}$ land of this plant was donated by the university and the equipment and building construction costs were donated by Kitakyushu city government. Monthly operational costs are 125 USD for the labors and 60 USD for management. The average Indonesian inflation rate of $12.26 \%$ was incorporated to estimate the annual increase of operation and maintenance costs. Income sources are from selling the compost products at a price of $70 \mathrm{USD} /$ tonne. A realistic price increase of $10 \%$ of organic compost fertilizer was assumed. The average Indonesian interest rate of $8.12 \%$ is incorporated for the NPV calculation.

NPV result for Rungkut Lor composting plant is 5,941 USD or about 9,902 per ton, BCR is 1.08 and amortization period can be achieved in the sixth year. It reveals that this project is feasible and although the achieved margin is very low, it is still financially profitable.

The Sri Lankan composting plant selected for this study is located in Matale city with organic waste input capacity of 1 TPD. This plant produces 0.3 TPD compost and sold at 180 USD per ton at the market. According to the plant manager, it was able to keep the high price for their compost products, because the quality of compost is good and it received a compost quality certification from the Ministry of Agriculture. Furthermore, the plant has developed and continues to practice efficient marketing strategies. In addition, the plant receives some other incomes from selling the recyclables and the collection fee paid by the served residences and local markets. The investment costs including a $600 \mathrm{~m}^{2}$ area of land whose leasing price would have been 3,000 USD for an entire lifetime was granted by municipal government to the local Non-Governmental Organization (NGO) called Sevanatha who is running the compost project. The building construction cost of 23,000 USD and the equipment cost of 4,700 USD were granted by United Nations Economic and Social Commission for Asia and the Pacific (UNESCAP). The construction cost is much higher than the simple windrow plant in the same scale (Surabaya) due to the spending of additional costs for making brick boxes for compost treatment. The operational costs include the salary for a 
technician (125 USD) and a worker (60 USD). The average Sri Lankan inflation rate of $10.4 \%$ was incorporated for the annual cost increase and interest rate of $8.47 \%$ was employed as the discount rate for the NPV calculation. Estimated price increase of fertilizer is $10 \%$. This assumption is made based on the price increase of various kinds of fertilizers commonly used in plantations in Sri Lanka (Gunathilake 2012). NPV result for Matale composting plant is 33,194 USD, BCR is 1.12 and amortization period can be achieved within a 7-year period. Similar to the Surabaya case study, this project is also financially feasible with low-profit margin.

\section{Medium-scale composting plant}

The medium-scale composting plant selected for this study is located in Temesi village, Gianyar regency in Bali. This plant is registered as CDM project and receiving $60 \mathrm{TPD}$ manually pre-sorted wastes. Among total waste, about $85 \%$ (51 TPD) is organic waste and uses for composting. The rest of residuals are disposed of in the nearby final disposal site. The plant uses the forced aeration technique and its composting production ratio is $30 \%$ of the inputs. The final product is sold at 1,000 IDR per $\mathrm{kg}$, or about 106 USD per ton at the retail market when sold in the $20-\mathrm{kg}$ packages. However, the selling price of the bulk is about 53 USD/ton (Zurbruegg et al. 2012). The project also receives income from CER of 23 USD per ton CO2-eq up to end of 2012 that decreases yearly by one USD and will stop at 17 USD in year 2018. The project investment costs were donated by Swiss Development Cooperation (SDC), United States Agency for International Development (USAID), Rotary Club Hamburg, Rotary Club Atlanta, Japan International Cooperation Agency (JICA), and Bali hoteliers (Boer et al. 2008; Nakamura et al. 2012). Similar to the Surabaya case study, the discount rate of $8.12 \%$, the inflation rate of $12.26 \%$, and fertilizer price increase of $10 \%$ were incorporated in the financial calculation. The results are as follows: a predicted 7,158,681 USD of total NPV or about 140,336 USD per ton waste treatment capacity, 3.05 CBR and 3-year amortization period.

\section{Large-scale composting plants}

Bantar Gebang composting site in Bekasi, Indonesia, is treating the waste from the Kramat Jati central market in Jakarta. The waste contains vegetable, fruits, and straw fruit baskets. The composting technology used at the plant is the windrow composting method. Responding to market demand, output product is pelletized and packed in $60-\mathrm{kg}$ packages used for agriculture, such as, cassava plantation, palm oil plantation, and rice farms. The received amount of market waste is 200 TPD. The final product is 30 TPD of pelletized compost fertilizer. About $60-70 \%$ of the products is sold at 1,000 Indonesian Rupiah or about 106 USD/tonne. The residue is disposed of in a nearby landfill or sold by scavengers for plastic recycling. The Jakarta government pays $11 \mathrm{USD} /$ tonne of waste tipping fee. $20 \%$ of this fee is paid as land rent fee to the Bekasi city government and the remaining $80 \%$ is used for paying the plant operators (Pikiran Rakyat 2011). The tipping fee increases about $5 \%$ annually (Kompas 2010). Costs related to transportation, such as, the 4-tonnes capacity trucks and the truck drivers' wages, are paid by the cleansing department. 160 people, who mostly used to work as scavengers in the nearby landfill, are paid 127 USD per person. Similar to the other Indonesian composting plants in this study, the discount rate of $8.12 \%$, the inflation rate of $12.26 \%$ and fertilizer price increase of $10 \%$ were assumed in the financial calculation. Results show that the NPV of this project is $40,573,301$ USD or about 202,867 USD per ton waste treatment capacity. The CBR is 1.77 and amortization period may be reached on the 6th year of the production lifetime. It reviews that the project is estimated to be profitable.

Beijing Nangong composting plant receives 638 TPD of municipal waste, in which 172.6 TPD is used as landfill cover soil and 465.4 TPD is processed into compost fertilizer using tunnel-composting systems with forced aeration technology. The sellable product is 65.7 TPD. Depending on the quality, price ranges from 7.8 to 12.6 USD/tonne. The remainder is given to farmers with no charge. The government of Beijing granted a land area of $66,000 \mathrm{~m}^{2}$. The investment cost for machinery, equipment and building was 26.6 million USD or about 72,282 per ton waste treatment capacity. The government of Beijing subsidizes the operation and maintenance cost, which equals to 15.86 USD per ton waste treated as the tipping fee. For the annual operation and maintenance cost calculation, the applied China inflation rate is $4.3 \%$ and the discount rate applied for NPV calculation is $6.5 \%$. The municipal waste compost fertilizer price increase is assumed to be $10 \%$.

The total NPV result of Nangong composting plant is 294 million USD or about $-545,538$ per ton waste treatment capacity, CBR is 0.77 and amortization time cannot be achieved in the 15 years assumed lifetime. The results imply that the project is not financially profitable. Additional cost arising in a large-scale composting plant is the transportation cost. However, Nangong composting plant does not bear this cost because it is borne by the government-appointed Transportation Company.

Table 3 summarizes the investment cost, annual operation and maintenance cost, and NPV for per ton capacity, BCR and the amortization period of the above-described plants. 
Table 3 Tables of investment, cost, benefit, NPV, BCR, and amortization in USD

\begin{tabular}{|c|c|c|c|c|c|}
\hline Plant name & Rungkut Lor ${ }^{\mathrm{a}}$ & Matale $^{\mathrm{b}}$ & Temesi $^{\mathrm{c}}$ & Bantar Gebang ${ }^{\mathrm{d}}$ & Nangong ${ }^{\mathrm{e}}$ \\
\hline Plant capacity (TPD) & 0.6 & 1 & 51 & 200 & 638 \\
\hline \multicolumn{6}{|l|}{ USD/Ton waste treatment capacity } \\
\hline Investment cost & 3,700 & 21,300 & 3,729 & 10,859 & 72,282 \\
\hline 1st year operation and maintenance cost & 3,700 & 21,300 & 3,729 & 10,705 & 10,330 \\
\hline NPV & 9,902 & 33,194 & 140,366 & 202,867 & $-545,538$ \\
\hline BCR & 1.08 & 1.12 & 3.05 & 1.77 & 0.77 \\
\hline Amortization period & 6 years & 7 years & 3 years & 6 years & Never \\
\hline
\end{tabular}

Investment cost granted by local university and Kitakyushu city government. Conversion rate 1 USD $=9,433$ IDR

${ }^{a}$ Source: KITA, Kitakyushu International Techno-cooperative Association

${ }^{\mathrm{b}}$ Land is leased from the municipal government by Sevantha NGO. Conversion rate 1 USD $=115$ LKR

c Sources: (Zurbruegg et al. 2012), (Kueper 2012). Investment costs were donated by SDC, USAID, Rotary Club Hamburg, Rotary Club Atlanta, JICA, and Bali hoteliers. Conversion rate $1 \mathrm{USD}=9,433$ IDR

d Source: Managing director of Bantar Gebang integrated disposal site, Lumban Toruan. Land, which is owned by Bekasi city government, is leased to Jakarta provincial government. Lease fee is $20 \%$ of the tipping fee. $80 \%$ of the tipping fee goes to plant operators (PT Godang Tua Jaya and PT Navigat Organic Energy Indonesia)

e Source: Zheng 2012. Land was granted by the government of Beijing

Table 4 Details of pessimistic scenarios

\begin{tabular}{ll}
\hline Pessimistic scenario & Absence of \\
\hline 1 & Tipping fee \\
2 & Initial cost (land and machineries) \\
3 & CER \\
4 & Tipping fee, initial cost, and CER \\
\hline
\end{tabular}

Estimated amortization time was calculated by the estimated cumulated cash flow. The year when cash flow cumulative becomes positive is the year when pay back is achieved. Table 4 summarizes the cumulative cash flow of each plant per ton waste treatment capacity.

\section{NPV, CBR and amortization time}

In the four smaller plant capacities, NPV seemed to increase, but it becomes extremely unprofitable in the gigantic 638 TPD plant. Furthermore, the CBR and amortization time results from the different capacities of composting plant in this study showed an interesting trend; they get better as it approaches the medium scale and worsen off as the capacity moves away from the medium scale (see Table 3). This finding indicates that the medium-scale composting plant may have the best financial performance.

\section{Sensitivity analysis}

Because all of the composting plants presented in this study received some support either from the government, university, NGO or other institution and organization, four pessimistic scenarios were constructed in this study to see how the plants would perform under the absence of these financial supports. The first scenario is the absence of the tipping fee, the second scenario is the absence of the initial cost including land and machineries, the third scenario is the absence of CER benefit, and the fourth scenario is the absence of all external supports (tipping fee, the initial cost, and CER) in all plants. The list of assumptions is shown in Table 4 and the accumulated cash flow of business of usual under ideal situation is shown in Table 5.

In the first pessimistic scenario, where tipping fee was absent (but the other income such as CER and land and initial costs in the business as usual), the $1 \mathrm{TPD}, 200 \mathrm{TPD}$, and 638 TPD plants suffered the most. Collection fee in a small-scale Matale plant of 3,960 USD/year is quite significant in proportion to the expenditures; the large-scale Bekasi plant receives a large amount of 3,679,820 USD tipping fee per year; and in large-scale Nangong plant the tipping fee is almost equivalent to the whole operation and maintenance cost. Without tipping fee, a 3-year delay of payback time in the Bekasi plant would be expected. The Matale and Nangong plant would be financially unsustainable (Table 6).

In the second pessimistic scenario, where initial fee was set to absent (another income in the business as usual), the payback time in the 0.6 TPD Surabaya plant would not be achievable within the 15 years assumed life time, a significant 9-year delay of payback time in the 1 TPD Matale plant was to be expected, and several years of payback time delay would be expected for both the medium- and largescale composting plants in Indonesia. Initial fee mainly includes of land and machineries. In addition to the first 2,200 operational cost, the initial machinery and land cost 
Table 5 Comparative table of cumulative cash flow in USD per ton waste treatment capacity (business as usual under ideal situation)

\begin{tabular}{lrrrrr}
\hline Year & 0.6 TPD & \multicolumn{1}{c}{1 TPD } & 51 TPD & 200 TPD & 638 TPD \\
\hline 1 & $(3,700)$ & $(39,510)$ & $(7,982)$ & $(21,437)$ & $(85,648)$ \\
2 & $(6,425)$ & $(33,087)$ & $(4,901)$ & $(19,893)$ & $(90,173)$ \\
3 & $(4,461)$ & $(26,163)$ & 2,472 & $(16,298)$ & $(94,699)$ \\
4 & $(2,478)$ & $(18,700)$ & 10,192 & $(10,456)$ & $(99,224)$ \\
5 & $(497)$ & $(10,661)$ & 18,268 & $(2,153)$ & $(103,749)$ \\
6 & 1,460 & $(2,006)$ & 26,592 & 8,846 & $(108,274)$ \\
7 & 3,361 & 7,306 & 35,079 & 22,799 & $(112,799)$ \\
8 & 5,170 & 17,320 & 43,766 & 39,988 & $(117,323)$ \\
9 & 6,843 & 28,082 & 52,692 & 60,724 & $(121,847)$ \\
10 & 8,329 & 39,640 & 61,900 & 85,347 & $(126,371)$ \\
11 & 9,564 & 52,046 & 71,437 & 114,231 & $(130,894)$ \\
12 & 10,475 & 65,352 & 79,471 & 147,787 & $(135,418)$ \\
13 & 10,975 & 79,612 & 86,176 & 186,465 & $(139,940)$ \\
14 & 10,960 & 94,883 & 93,610 & 230,758 & $(144,462)$ \\
15 & 10,311 & 111,222 & 101,840 & 281,212 & $(148,984)$ \\
\hline
\end{tabular}

Figures in the bracket imply negative value

Table 6 Comparative table of pessimistic scenarios 1 (no tipping fee) cumulative cash flow in USD per ton waste treatment capacity

\begin{tabular}{lrrrrr}
\hline Year & 0.6 TPD & \multicolumn{1}{l}{ TPD } & 51 TPD & 200 TPD & 638 TPD \\
\hline 1 & $(3,700)$ & $(43,470)$ & $(7,982)$ & $(23,873)$ & $(91,415)$ \\
2 & $(6,425)$ & $(45,379)$ & $(4,901)$ & $(27,324)$ & $(107,725)$ \\
3 & $(4,461)$ & $(47,653)$ & 2,472 & $(28,973)$ & $(124,540)$ \\
4 & $(2,478)$ & $(50,345)$ & 10,192 & $(28,638)$ & $(141,884)$ \\
5 & $(497)$ & $(53,517)$ & 18,268 & $(26,117)$ & $(159,779)$ \\
6 & 1,460 & $(57,240)$ & 26,592 & $(21,189)$ & $(178,249)$ \\
7 & 3,361 & $(61,592)$ & 35,079 & $(13,610)$ & $(197,318)$ \\
8 & 5,170 & $(66,663)$ & 43,766 & $(3,115)$ & $(217,012)$ \\
9 & 6,843 & $(72,555)$ & 52,692 & 10,593 & $(237,358)$ \\
10 & 8,329 & $(79,383)$ & 61,900 & 27,837 & $(258,385)$ \\
11 & 9,564 & $(87,276)$ & 71,437 & 48,974 & $(280,120)$ \\
12 & 10,475 & $(96,379)$ & 79,471 & 74,394 & $(302,595)$ \\
13 & 10,975 & $(106,859)$ & 86,176 & 104,529 & $(325,842)$ \\
14 & 10,960 & $(118,902)$ & 93,610 & 139,853 & $(349,894)$ \\
15 & 10,311 & $(132,716)$ & 101,840 & 180,888 & $(374,784)$ \\
\hline
\end{tabular}

Figures in the bracket imply negative value

in the Surabaya plant is 19,400 USD. This cost is too expensive for the plant to sustain itself financially. Under the assumption that the land for the 200 TPD Bekasi plant had to be purchased, it would have required an extra $3,180,324$ USD to the first cash outflow because based on a local survey, land price in Bantar Gebang Bekasi is about $53 \mathrm{USD} / \mathrm{m}^{2}$. Bantar Gebang composting area occupies $20,000 \mathrm{~m}^{2}$ out of the 110-ha waste management area. The land of Temesi plant is $4,700 \mathrm{~m}^{2}$ and a local survey revealed that the land price in Temesi, Gianyar is $84 \mathrm{USD} / \mathrm{m}^{2}$.
Table 7 Comparative table of pessimistic scenarios 2 (no initial support) cumulative cash flow in USD per ton waste treatment capacity

\begin{tabular}{lrrrrl}
\hline Year & 0.6 TPD & \multicolumn{1}{l}{ TPD } & 51 TPD & 200 TPD & 638 TPD \\
\hline 1 & $(36,033)$ & $(107,310)$ & $(23,613)$ & $(53,240)$ & $(196,571)$ \\
2 & $(71,092)$ & $(100,887)$ & $(20,533)$ & $(51,696)$ & $(201,097)$ \\
3 & $(69,128)$ & $(93,963)$ & $(13,159)$ & $(48,101)$ & $(205,622)$ \\
4 & $(67,145)$ & $(86,500)$ & $(5,440)$ & $(42,259)$ & $(210,148)$ \\
5 & $(65,163)$ & $(78,461)$ & 2,636 & $(33,956)$ & $(214,673)$ \\
6 & $(63,207)$ & $(69,806)$ & 10,960 & $(22,957)$ & $(219,198)$ \\
7 & $(61,306)$ & $(60,494)$ & 19,447 & $(9,005)$ & $(223,722)$ \\
8 & $(59,497)$ & $(50,480)$ & 28,134 & 8,184 & $(228,247)$ \\
9 & $(57,824)$ & $(39,718)$ & 37,060 & 28,920 & $(232,771)$ \\
10 & $(56,338)$ & $(28,160)$ & 46,268 & 53,544 & $(237,295)$ \\
11 & $(55,103)$ & $(15,754)$ & 55,806 & 82,428 & $(241,818)$ \\
12 & $(54,191)$ & $(2,448)$ & 63,840 & 115,984 & $(246,341)$ \\
13 & $(53,692)$ & 11,812 & 70,545 & 154,661 & $(250,864)$ \\
14 & $(53,706)$ & 27,083 & 77,979 & 198,955 & $(255,386)$ \\
15 & $(54,356)$ & 43,422 & 86,209 & 249,408 & $(259,908)$ \\
\hline
\end{tabular}

Figures in the bracket imply negative value

Based on this, an additional 398,600 USD was added to the pessimistic scenario of the medium plant (Table 7).

In the third scenario, where CER was eliminated (but another income is in the business as usual), the mediumscale Temesi plant would have several years of payback time delay. Note that the assumed lifetime is for 15 years while the CER income is only scheduled until the 11th year. If machinery and spare-parts need to be repurchased before the assumed 15 years lifetime; the delay would have been more significant (Table 8).

In the fourth pessimistic scenario, tipping fee, the initial investment, and CER were eliminated. In this scenario, all plants financially suffer quite significantly. Three out of the plants would never achieve payback time within the assumed 15-year lifetime. The medium-scale Temesi plant payback would be delayed to the 10th year, and the largescale Bekasi plant payback would be delayed to the 11th year (Table 9).

\section{Conclusions and recommendations}

This study made attempts to investigate the optimum range of municipal waste composting in developing Asian countries. Site visits, interview with plant managers, and data provided by the relevant organizations ensured the authenticity of data used in this study.

The results revealed that the medium-scale (51 TPD) and lower large-scale (200 TPD) composting plants have a better opportunity to be financially sustainable. The waste input and product quality of these plants are more 
Table 8 Comparative table of pessimistic scenarios 3 (no CER) cumulative cash flow in USD per ton waste treatment capacity

\begin{tabular}{lrrrrr}
\hline Year & 0.6 TPD & \multicolumn{1}{c}{1 TPD } & 51 TPD & 200 TPD & 638 TPD \\
\hline 1 & $(3,700)$ & $(39,510)$ & $(9,335)$ & $(21,437)$ & $(85,648)$ \\
2 & $(6,425)$ & $(33,087)$ & $(10,313)$ & $(19,893)$ & $(90,173)$ \\
3 & $(4,461)$ & $(26,163)$ & $(8,351)$ & $(16,298)$ & $(94,699)$ \\
4 & $(2,478)$ & $(18,700)$ & $(6,044)$ & $(10,456)$ & $(99,224)$ \\
5 & $(497)$ & $(10,661)$ & $(3,379)$ & $(2,153)$ & $(103,749)$ \\
6 & 1,460 & $(2,006)$ & $(350)$ & 8,846 & $(108,274)$ \\
7 & 3,361 & 7,306 & 3,079 & 22,799 & $(112,799)$ \\
8 & 5,170 & 17,320 & 6,942 & 39,988 & $(117,323)$ \\
9 & 6,843 & 28,082 & 11,280 & 60,724 & $(121,847)$ \\
10 & 8,329 & 39,640 & 16,135 & 85,347 & $(126,371)$ \\
11 & 9,564 & 52,046 & 21,555 & 114,231 & $(130,894)$ \\
12 & 10,475 & 65,352 & 27,589 & 147,787 & $(135,418)$ \\
13 & 10,975 & 79,612 & 34,294 & 186,465 & $(139,940)$ \\
14 & 10,960 & 94,883 & 41,728 & 230,758 & $(144,462)$ \\
15 & 10,311 & 111,222 & 49,958 & 281,212 & $(148,984)$ \\
\hline
\end{tabular}

Figures in the bracket imply negative value

Table 9 Comparative table of pessimistic scenario 4 (no tipping fee, no initial support, no CER) cumulative cash flow in USD per ton waste treatment capacity

\begin{tabular}{lllrrl}
\hline Year & 0.6 TPD & \multicolumn{1}{l}{1 TPD } & 51 TPD & 200 TPD & 638 TPD \\
\hline 1 & $(36,033)$ & $(111,270)$ & $(24,966)$ & $(55,676)$ & $(202,339)$ \\
2 & $(71,092)$ & $(113,179)$ & $(25,945)$ & $(59,127)$ & $(218,648)$ \\
3 & $(69,128)$ & $(115,453)$ & $(23,983)$ & $(60,776)$ & $(235,464)$ \\
4 & $(67,145)$ & $(118,145)$ & $(21,675)$ & $(60,441)$ & $(252,808)$ \\
5 & $(65,163)$ & $(121,317)$ & $(19,011)$ & $(57,920)$ & $(270,703)$ \\
6 & $(63,207)$ & $(125,040)$ & $(15,981)$ & $(52,992)$ & $(289,172)$ \\
7 & $(61,306)$ & $(129,392)$ & $(12,553)$ & $(45,414)$ & $(308,242)$ \\
8 & $(59,497)$ & $(134,463)$ & $(8,689)$ & $(34,918)$ & $(327,936)$ \\
9 & $(57,824)$ & $(140,355)$ & $(4,352)$ & $(21,210)$ & $(348,282)$ \\
10 & $(56,338)$ & $(147,183)$ & 504 & $(3,966)$ & $(369,308)$ \\
11 & $(55,103)$ & $(155,076)$ & 5,923 & 17,170 & $(391,044)$ \\
12 & $(54,191)$ & $(164,179)$ & 11,958 & 42,591 & $(413,519)$ \\
13 & $(53,692)$ & $(174,659)$ & 18,662 & 72,726 & $(436,766)$ \\
14 & $(53,706)$ & $(186,702)$ & 26,097 & 108,050 & $(460,817)$ \\
15 & $(54,356)$ & $(200,516)$ & 34,326 & 149,085 & $(485,708)$ \\
\hline
\end{tabular}

Figures in the bracket imply negative value

controllable than larger scale composting plants. They can also earn extra income from tipping fees and CER that is hardly possible to get in the small-scale plants. The compost quality can be enhanced by manually separating organic waste in Bali plant or by pelletizing the waste in Bekasi plant that results in increasing the market acceptance of their products. Another successful strategy adopted was the agreement between Bantar Gebang plant and the Department of Agriculture, where a significant amount of the products is utilized in plantations. The role of government and institutions, such as, providing investment cost of the small-scale composting plant and providing tipping fee for large-scale composting plants, is significant in determining the economic feasibility of the plants. Awareness of these successful strategies may contribute to the improvement of composting plant economic performance.

\section{Further studies}

Although this study has identified the general economic performance estimation on different scales of composting plants, more detailed study dedicated to comparing the nutrient and heavy metals contained in the product of different-scale composting plant would be useful for the product-oriented practitioners. Further discussion on techniques, schemes, and design of efficient policy to encourage organic waste source separation would benefit many growing cities struggling with the increasing volume and waste composition diversity.

Moreover, benefits of composting such as waste volume reduction, benefits related to soil rehabilitation from manmade chemical contamination, and social impact such as improvement of environmental awareness due to community engagement and number of employment created from composting would be important to be analyzed. Holistic and comprehensive understanding of the benefits in various aspects may attract better supports from stakeholders and policy makers.

Acknowledgments The authors thank the composting plant managers, institutions, and national municipal waste management consultants who have generously contributed data and information for this research.

Conflict of interest The authors declare that there is no competing interest.

Open Access This article is distributed under the terms of the Creative Commons Attribution License which permits any use, distribution, and reproduction in any medium, provided the original author(s) and the source are credited.

\section{References}

Ali G, Vilas N, Abbas S, Sabir M (2012) Green waste to biogas: renewable energy possibilities for Thailand's green markets. Renew Sustain Energy Rev 16:5423-5429

Ambulkar A, Shekdar A (2004) Prospects of biomethanation technology in the Indian context: a pragmatic approach. Resour Conserv Recycl 40:111-128

Asian Development Bank (ADB) (2011) Towards sustainable municipal organic waste management in South Asia: a guide for policy makers and practitioners. ADB, Manila 
Aye L, Widjaya E (2006) Environmental and economic analyses of waste disposal options for traditional markets in Indonesia. Waste Manag 26:1180-1191

Bhatia R (1977) Economic Appraisal of Bio-Gas Units in India: framework for social benefit cost analysis. Econ Polit Wkly 12:33-34

Boer R, Dewi R, Ismawati Y, Anggraini S (2008) Country: Indonesia. Financing local low carbon development. http://dp2m.umm.ac. id/files/file/financinglocallowcarbondevelopment_indonesia.pdf. Accessed 7 Jan 2012

Brinton WF (2000) Compost quality standards and Guidelines. Woods and research laboratory: http://compost.css.cornell.edu/ Brinton.pdf. Accessed 23 Apr 2014

Christianto (2005) Teknik pengomposan metode open windrow. Pusdakota Ubaya: http://nusataniterpadu.files.wordpress.com/ 2009/08/isi-buku.pdf. Accessed 02 Apr 2014

Demir A, Arisoy M (2007) Biological and chemical removal of $\mathrm{Cr}(\mathrm{VI})$ from waste water: cost and benefit analysis. J Hazard Mater 147:275-280

Eawag Sandec (2008) Sandec Training Tool 1.0-module 4. Water and sanitation in developing countries. http://www.sswm.info/ sites/default/files/reference_attachments/EAWAG\%20SAN DEC\%202008\%20Module\%204\%20Sanitation\%20Systems\% 20and\%20Technologies\%20-\%20Presentation.pdf. Accessed 11 Jan 2012

Fenhann J (2012) CDM Pipeline Overview. UNEP Risoe Centre: http://www.cdmpipeline.org/. Accessed 7 Sep 2012

Finnveden G, Bjoerklund A, Moberg A, Ekvall T (2007) Environmental and economic assessment methods for waste management decision-support: possibilities and limitations. Waste Manag Res 25(3):263-269

Gunathilake HAJ (2012) Fertilizer usage for coconut and intercrops in Sri Lanka. Advance agricultural practice: http://www.advancea griculturalpractice.in/w/images/3/37/Fertilizer_usage_for_Coco nut_and_Intercrops_in_Sri_Lanka.pdf. Accessed 7 Nov 2012

Haaren R (2009) Large scale aerobic composting of source-separated organic wastes: a comparative study of environmental impacts, costs, and contextual effects. Foundation of Engineering and Applied Science, Earth and Environmental Engineering. Columbia University, New York

Hargreaves JC, Adl MS, Warman PR (2008) A review of the use of composted municipal solid waste in agriculture. Agric Ecosyst Environ 123:1-14

Hogg D (2002) Costs for municipal waste management in the EU. Eunomia Research and Consulting. European Commission, Brussels

Hoornweg D, Bhada-Tata P (2012) What a waste: a global review of solid waste management. World Bank, Washington DC

International Institute for Sustainable Development (2012) A Citizens' guide to energy subsidies in Indonesia. http://www.iisd. org/gsi/sites/default/files/indonesia_czguide_eng.pdf. Accessed 13 July 2012

Jayaratne KA (2009) Eco-efficient and sustainable urban infrastructure in Asia and Latin America. Expert Group Meeting. http:// www.cepal.org/dmaah/noticias/paginas/3/35703/session-8matale.pdf. Accessed 23 Apr 2014

Jayaratne KA (2013) Partnerships for sustainable municipal solid waste management system: Integrated Resource Recovery Center Program in Sri Lanka. Presentation made at National Workshop on Compost MSW. Sri Lanka, IRRC, 2013

Kueper D (2012) Temesi business plan, for the Gianyar Waste Recovery Project. http://www.temesirecycling.org/download/ new/Temesi\%20Business\%20Plan.pdf. Accessed 7 Oct 2012

Kompas (2010) Megapolitan. News. http://nasional.kompas.com/ $\mathrm{read} / 2010 / 07 / 01 / 19062770 /$ wah.tipping.fee.bantar.gebang.5665. juta. Accessed 7 Dec 2011
Mazumdar N (2012) India country situation report on municipal solid waste management and composting submitted Institute of Global Environmental Strategies (IGES). IGES, Kitakyushu

Menikpura S, Gheewala S, Bonnet S (2012) Framework for life cycle sustainability assessment of municipal solid waste management systems with an application to a case study in Thailand. Waste Manag Res 0:1-12

Mishan EJ (1972) Cost-benefit analysis. George Allen \& Unwin, London

Nakamura $\mathrm{H}$ et al. (2012) Carbon finance for low-carbon community development. Institute for Global Environmental Strategies: EnviroScope: http://enviroscope.iges.or.jp/modules/envirolib/ upload/2645/attach/iges\%20carbon\%20finance\%20report\% 20final\%20p.pdf. Accessed 7 Nov 2012

Ngoc UN, Schnitzer H (2009) Sustainable solutions for solid waste management in Southeast Asian countries. Waste Manag 29(6):1982-1995

Ong LL (1997) Burgernomics: the economics of the Big Mac standard. J Int Money Financ 16:865-878

Pandyaswargo AH, Onoda H, Nagata K (2012) Energy recovery potential and life cycle impact assessment of municipal solid waste management technologies in Asian countries using ELP model. Int J Energy Environ Eng 3:28

Pikiran Rakyat (2011) Pikiran Rakyat Online: http://www.pikiranrakyat.com/node/139760. Accessed 7 Dec 2012

Premakumara DGJ, Abe M, Maeda T (2011) Reducing municipal waste through promoting integrated sustainable waste management (ISWM) practices in Surabaya City, Indonesia, ecology and waste management, vol 144. WIT Press, UK, pp 457-470

Pusdakota (2014) Pusdakota: http://gtps.ampl.or.id/index2.php?op tion=com_content\&do_pdf=1\&id=68. Accessed 02 Apr 2014

Rand T, Hankohl J, Marxen U (2000) Municipal solid waste incineration: a decision maker's guide. World Bank, Washington DC

Reich CM (2005) Economic assessment of municipal waste management systems - case studies using a combination of life cycle assessment (LCA) and life cycle costing (LCC). J Clean Prod 13:253-263

Sang-Arun J, Bengtsson M, Mori H (2009) Practical guide for improved organic waste management. Institute of Global Environmental Strategies (IGES), Hayama

Skovgaard M, Karin I, Tomas E (2007) Nordic guideline for costbenefit analysis in waste management. Nordic cooperation. Nordic Council of Ministers, Denmark

Soeylemez M (2000) On the optimum heat exchanger sizing for heat recovery. Energy Convers Manag 41:1419-1427

The Economist (2014) The Big mac Index, full data-set. The Economist: http://media.economist.com/sites/default/files/ media/2014InfoG/databank/BMfile2000-Jan2014.xls. Accessed 23 Apr 2014

Trading Economics Interest rate by country (2012) Trading economics: http://www.tradingeconomics.com/interest-rates-list-bycountry. Accessed 07 Apr 2012

UNEP (2009) Developing integrated solid waste management plan: training manual. Assessment of current waste management system and gaps therein. International Environmental Technology Centre, Division of Technology, Industry and Economics, vol 2, UNEP, Osaka

UN ESCAP (United Nations Economic and Social Commission for Asia and the Pacific), Waste Concern and Sevanatha Urban Resource Center (2010) Resource recovery options baseline survey. waste2resource.org: http://waste2resource.org/wp-con tent/uploads/2014/03/Matale-Baseline.pdf. Accessed $23 \mathrm{Apr}$ 2014

Williams PT (2005) Waste treatment and disposal. Wiley, West Sussex 
Yenneti K, Premakumara DGJ (2011) Carbon finance and decentralised composting projects. Institute for Global Environmental Strategies (IGES), Kitakyushu

Zheng G (2012) China National Overview/Country Situation Report On municipal solid waste management and composting submitted Institute of Global Environmental Strategies (IGES). IGES, Kitakyushu

Zurbruegg C, Drescher S, Patel A, Sharatchandra HC (2004) Decentralised composting of urban waste-an overview of community and private initiatives in Indian cities. Waste management 24:655-662

Zurbruegg C, Gfrerer M, Ashadi H, Werener B, David K (2012)

Determinants of sustainability in solid waste management-the

Gianyar waste recovery project in Indonesia. Waste Manag 32:2126-2133 